\title{
Mencari Solusi Konstitusional untuk Integrasi Nasional
}

\author{
Ni'matul Huda
}

When freedom of speech arises in this reformation era, the voice for creation the more just and democratic governance appears every time. Integralism state, then, believed as not relevant anymore to accommodate the plurality of society, and conversely, federalism which is becoming more popular today, seems to be more appropriate for Indonesia. However, before going further to federalism, local autonomy is regarded as a promising instrument to set up national integrity.

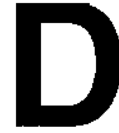

esakan beberapa daerah kepada pemerintah Pusat agar mereka diberi kebebasan untuk mengelola daerahnya (otonomi) - bahkan kalau mungkin mereka minta pisah/terlepas dari Negara Kesatuan Republik Indonesia atau mempersoalkan kembali bentuk negara kesatuan dan menggantinya menjadi negara federal akhir-akhir ini, antara lain disebabkan adanya kesenjangan yang luar biasa antara Pusat dan Daerah khususnya dalam bidang ekonomi dan politik yang diciptakan oleh penguasa Orde Baru sehingga menimbulkan ketidakadilan di masyarakat.

Secara ekonomis, Daerah tidak pernah mendapatkan sumber pendanaan yang memadai. Menurut Daniel Dhakidae, negara kesatuan mulai dipersoalkan dari banyak segi: efisiensi, efektivitas, keadilan, economic inequality, dan regional inequality. Selama pemerintahan Orde Baru tidak ada yang namanya perimbangan keuangan antara Pusat dan Daerah, bahkan daerah penghasil uang seperti Irian Jaya hanya mendapat empat persen, Kalimantan Timur hanya mendapat satu persen, dan Aceh hanya mengkonsumsi setengah persen dari yang diterima dari pengolahan sumber daya lokal masing-masing, selebihnya mengalir ke Pusat. Angka-angka di atas sudah menunjukkan ketimpangan luar biasa. Sumber daya di daerah tidak berkembang. Dalam arti human resources, 10 calleadership dan local natural resources, kalaupun ada, semuanya milik Pusat. Semua itu yang menghidupkan kembali, atau sekurang-kurangnya membuka keinginan 
pemikiran ke arah sistem federal. ${ }^{1}$

Munculnya berbagai pemikiran bahkan tuntutan untuk meninggalkan bentuk negara kesatuan dan beralih ke federal, menurut Buyung Nasution, lebih disebabkan kenyataan telah terdistorsinya konsep "kesatuan" (unitary) menjadi "persatuan dan kesatuan" yang lebih dekat kepada "penyeragaman" (uniform). Akibatnya, berbagai perbedaan yang ada tidak dilihat sebagai aneka kekayaan dalam rangka kebhinekaan, melainkan lebih dilihat sebagai potensi ancaman yang karenanya harus ditundukkan di bawah "persatuan dan kesatuan" melalui sentralisasi kekuasaan. ${ }^{2}$

Secara politis, Daerah tidak pernah mendapatkan "kebebasan" untuk menentukan masa depan daerahnya sesuai corak dan dinamika yang diinginkan oleh masyarakat setempat. Semuanya "serba" ditentukan oleh Pusat. DPRD sebagaimana halnya DPR, juga tidak memiliki peran yang signitikan dalam mengembangkan demokrasi di daerah. Kepala daerah yang juga sekaligus sebagai kepala wilayah dijadikan

- Daniel Dhakidae, "Federalisme, Mungkinkah Bagi Indonesia", dalam Adnan Buyung Nasution, Harun Alrasid, Ichlasul Amal, dkk, Federalisme Untuk Indonesia, PT Kompas Media Nusantara, Jakarta, 1999, hal. xxvi. Ada sementara pihak yang memahami kata federal, federasi itu dalam arti yang negatif, yaitu dikaitkan dengan kehendak separatis dan disintegrasi. Seakan-akan dengan bentuk federal maka kita akan melakukan pemisahan diri darj Negara Republik Proklamasi ini; dan karena itu akan membuat Republik disintegratif, berantakan wujudnya. Lihat juga dalam Anhar Gonggong. 2001. Amandemen Konstitusi, Otonomi Daerah, dan Federalisme, Media Pressindo, Yogyakarta, hal. 7†-72.

2 Ibid., hal. 136-137. sebagai perpanjangan tangan pusat di daerah sebagai penguasa tunggal di daerah. Disamping itu, DPRD dikonstruksi menjadi bagian dari pemerintah daerah. sehingga hampir semua fungsi DPRD (fungsi legislasi, pengawasan, dan budgetef) tidak dapat berjalan dengan baik, hakhak anggota DPRD juga tidak pernah digunakan. Proses demokrasi tersumbat, tidak dapat berjalan sebagaimana mestinya.

Ada sejumlah kalangan yang berpandangan bahwa federalisme bisa menjadi salah satu jalan keluar terhadap persoalan hubungan Pusat dan Daerah saat ini, tetapi banyak kalangan yang mengkhawatirkan terhadap federalisme karena gejala ancaman disintegrasi sudah berada di pelupuk mata.

Kondisi tersebut di atas ikut melatar belakangi munculnya berbagai tuntutan masyarakat di daerah. Tuntutan tersebut kalau tidak direspon secara baik tentu akan membahayakan eksistensi Negara Kesatuan Republik Indonesia. Apa yang sudah terjadi di Timor Timur menjadi pelajaran yang sangat berharga bagi kita, agar daerah-daerah yang menginginkan memisahkan diri dari Negara Kesatuan RI dapat dicarikan jalan keluarnya dengan cara yang lebih baik.

Persoalan utama self determination secara umum timbul ketika terdapat sebagian entitas politik, subyek hukum secara kolektif menuntut hak untuk memisahkan diri atau bergabung dengan kesatuan organisasi politik yang besar (negara). Dalam wacana ilmiah asal-usul self determination, atau tekad untuk mengurusi dan menentukan nasib diri sendiri terkait dengan kekuatan penjajah atau kolonialisasi. Hal inj timbul terutama ketika negara-negara di bagian Asia dan Afrika berhasil membe- 
Topik : Mencari Solusi Konstitusional untuk Integrasi Nasional, Ni'matul Huda

baskan diri dari cengkeraman penjajahan dan kemudian muncul menjadi negaranegara yang merdeka. ${ }^{3}$

Tantangan dari luar yang juga berpotensi 'menggancam' integrasi nasional adalah kemampuan kita menghadapi pasar global, - sebagaimana yang diprediksikan oleh Kenichi Ohmae. Di akhir abad ke 20, sebuah era yang ditandai dengan munculnya globalisme atau sering juga disebut sebagai globalisasi, dimana pola kehidupan manusia dalam berbagai aspeknya mulai "teraduk menjadi satu" tanpa terikat lagi oleh batas-batas negara bangsa, peran dan efektifitas adanya negara bangsa mulai dipertanyakan. Negara bangsa yang dicirikan oleh adanya territorium, kontrol atas kekuasaan, struktur kekuasaan impersonal dan legitimasi, perlahan mulai kehilangan fungsinya. Empat variabel dalam globalisasi yang dapat dikatakan merupakan 'biang kerok impotensi' negara bangsa ini adalah empat, yaitu, Industri, Investasi, Individual dan Informasi. ${ }^{4}$ Ohmae pernah berujar tentang keadaan bentuk dan struktur kenegaraan Indonesia kepada wartawan Ummat, bahwa kalau bentuk dan struktur negara Indonesia tidak diubah, maka (bangsa) Indonesia didalam memasuki abad ke-21 hanya akan mampu

3 Jawahir Thontowi, "Tuntutan GAM Mengenai Self Determination Dalam Perspektif Hukum Internasional", makalah Diskusi Panel "Self Determination Dalam Perspektif Hukum Internasional, Hukum Islam dan Hukum Tata Negara", yang diselenggarakan oleh Departemen Hukum Internasional Fakultas Hukum Universit as Islam Indonesia Yogyakarta, 16 Juli 2002, hal. 2.

4 Kenichi Ohmae. 2002. Hancurnya Negara-Bangsa, Penerbit Qalam, Yogyakarta, 2002, hal. 3-6. bersaing dengan Myanmar. ${ }^{5}$

\section{Berkaca dari Lepasnya Timor Timur}

Senin 20 Mei 2002, telah lahir negara baru Timor Leste, bekas Propinsi ke-27 Negara Kesatuan RI yang dulu dikenal dengan nama Timor Timur. Dalam penuturan sejarah di berbagai wacana yang ada, dikatakan tanggal $20 \mathrm{Mei}$ adalah buah perjuangan selama 24 tahun rakyat Timor Timur. Bisa dikatakan, hari itu merupakan upaya menyambung benang kemerdekaan yang terputus. Tepatnya tanggal 28 November 1975. Timor Timur sempat memproklamasikan diri sebagai negara merdeka dan mengangkat Francisco Xavier do Amaral sebagai Presiden Republik Demokratik Timor." Malang, kemerdekaan itu hanya berlangsung sembilan hari. Atas dukungan penuh dari Amerika Serikat dan Australia, tanggal 7 Desember 1975, Indonesia secara bulat kemudian memutuskan memasuki Timor Timur melalui Operasi Seroja. Dan sejarah mencatat terjadilah integrasi yang dilakukan melalui pengingkaran Deklarasi Balibo tanggal 30 November 1975.

Indonesia mengesahkan keputusan itu dengan Undang-Undang No. 7 Tahun 1976, tanggal 17 Juli 1976 dan MPR mengukuhkan dengan Tap MPR No. VI/ MPR/1978 tanggal 22 Maret 1978. Sejak itu Timor Timur berada di bawah bimbingan Pemerintah Indonesia.

Sayang, Majelis Umum PBB tidak

5 Anhar Gonggong, Amandemen... Op.Cit., hal. 101-102.

- Kompas, Minggu, 19 Mei 2002. 
mengakui pengukuhan integrasi itu. Dengan kata lain, PBB tetap menganggap Timor Timur yang waktu itu masih disebut sebagai Timor Portugis sebagai non-self governing territory. Matthew Jardine ${ }^{7}$ mengatakan, "Lima hari setelah invasi, Majelis Umum PBB mengeluarkan resolusi yang menyesalkan invasi itu dan meminta Indonesia segera menarik diri untuk melaksanakan hak penentuan nasib sendiri." Menurut Jardine, Keputusan itu mendapat dukungan 72 suara, dengan 10 suara menentang, dan 43 abstain yang antara lain didukung AS, Kanada dan Eropa Barat.

Setelah berjalan kurang lebih 24 tahun kemudian, tepatnya Rabu, 27 Januari 1999, Presiden B.J. Habibie tiba-tiba membuat keputusan dengan menawarkan dua opsi, yakni pertama, diberi otonomi khusus yang diperluas; kedua, referendum. Dari kedua opsi tersebut ternyata masyarakat Timor Timur memilih untuk melakukan referendum.

Melalui kesepakatan 5 Mei 1999 antara Indonesia dan Portugal di bawah naungan Sekretaris Jenderal PBB di New York, jajak pendapat tak bisa dihindarkan. 30 Agustus 1999, Timor Timur melaksanakan penentuan pendapat yang dimenangkan telak oleh simpatisan prokemerdekaan dengan suara mayoritas 78,5 persen. Sejak saat itu kondisi keamanan di wilayah tersebut semakin mengkhawatirkan. Kemungkinan terjadinya pecah perang saudara susah untuk dihindarkan, karena dari kelompok prootonomi/prointegrasi menolak keras hasil jajak pendapat tersebut.

Oleh karena situasi yang kian mem-

7 Matthew Jardine. 1995. East Timor: Genocide in Paradise, Odonian Press, Tucson, Arizona. buruk di Timor Timur, pemerintah Indonesia akhirnya memutuskan bahwa mulai Selasa dini hari 7 September. 1999, keadaan darurat militer diberlakukan di Timor Timur sampai kondisi bisa dikendalikan. Pernyataan keadaan darurat militer tersebut dimuat didalam Keputusan Presiden No. 107 Tahun 1999. Sejak diberlakukannya darurat militer kondisi di wilayah tersebut bukannya membaik tetapi malah bertambah buruk, disamping itu tekanan dari dunia internasional juga bertubi-tubi kepada pemerintah Indonesia. Akhirnya pemerintah Indonesia mencabut pemberlakuan darurat militer di Timor Timur sejak 23 September 1999 melalui Keputusan Presiden No. 112 Tahun 1999, untuk selanjutnya ditetapkan tangga! penyerahan tanggungjawab ketertiban dan keamanan Timor Timur kepada Pasukan Multinasional PBB (INTERFET). Bersamaan dengan itu pula telah dikeluarkan Instruksi Presiden No. 12 Tahun 1999 tentang Pemulihan Kehidupan Masyarakat di Daerah Provinsi Timor Timur.

Sebagai negara berdaulat, posisi tawar (bargaining position) pemerintah Indonesia sangat lemah di mata internasional karena hasil jajak pendapat 30 Agustus 1999 memberikan jawaban yang realistis kepada dunia bahwa proses integrasi dengan Indonesia selama ini baru sebatas integrasi politik (wilayah) dan bukan integrasi bangsa yang seutuhnya. Perbedaan perolehan suara yang cukup telak $(78,5 \%: 21,5 \%)$ merupakan bukti bahwa rakyat Timor Timur menghendaki kemerdekaan. Dua dekade terkesan masih belum cukup untuk meyakinkan rakyat Timor Timur bahwa bergabung dengan Indonesia merupakan pilihan yang menguntungkan.

Terlepasnya Timor Timur dari 
Topik : Mencari Solusi Konstitusional untuk Integrasi Nasional, Ni'matul Huda

Negara Kesatuan RI melalui referendum (jajak pendapat) telah menimbulkan "inspirasi" bagi daerah lain untuk mengajukan tuntutan yang sama dari sebagian masyarakat di Propinsi Aceh, Irian Jaya (Papua), Riau dll, untuk mengadakan referendum. Kegaduhan sosial dan politik pun merebak dimana-mana, sepertinya kehilangan kendali sesaat untuk menangkis "serangan" yang bertubi-tubi dari daerah. Sungguh suatu warisan yang menyedihkan bagi generasi penerus - pasca Soeharto. Persatuan dan kesatuan yang selama ini diagungkan sebagai keunggulan bangsa ini, ternyata hanyalah semu dan sekarang mengalami keretakan yang mengkhawatirkan integrasi Indonesia.

\section{Prinsip-prinsip Self Determination}

Dalam hukum internasional istilah self determination bukan saja terjadi sebagai suatu transformasi prinsip-prinsip politik dan moral terhadap hak-hak hukum secara penuh, juga menjadi bagian penting dalam hukum internasional. Michla Pomerance telah menjelaskan bahwa self determination itu merupakan suatu penggabungan dari berbagai kecenderungan berpikir, yang sebagian mengaitkannya dengan kehendak untuk membuat suatu pemerintahan sendiri (self government), sedangkan bagian lain mengaitkan dengan pecahnya negara baru hasil dari perkembangan masa peperangan. Tetapi secara keseluruhan gerakan self determination sangat merindukan adanya spirit demokrasi, melalui suatu kesepakatan dari masyarakat (consent of the governed). Kesepakatan bersama dari masyarakat tersebut bisa diartikan hak sebagai masyarakat suatu wilayah untuk memilih suatu negara berdaulat dimana mereka dapat hidup, terbebas dari model pertuanan kekuatan asing. ${ }^{8}$

Prinsip-prinsip self determination yang diakui oleh hukum internasional yaitu Resolusi Majelis Umum PBB Nomor 1514. Desember 1960 antara lain: ${ }^{9}$

1. Penindasan dan suatu eksploitasi yang mengandung pelanggaran terhadap hak asasi manusia, adalah bertentangan dengan upaya mempromosikan citacita perdamaian dunia dan kerjasama.

2. Semua orang memiliki hak untuk menentukan nasibnya sendiri (self determination), didasarkan kepada hakhak kebebasan untuk menuntut hak-hak dan status politik, dan mereka memiliki kemerdekaan untuk memperoleh keuntungan secara sosial, ekonomi dan kebudayaan.

3. Tidak memadainya situasi ekonomi, sosial, budaya dan pendidikan suatu masyarakat tidak dapat dijadikan alasan bagi penundaan pemberian hak self determination.

4. Segala tindakan militer dan penggu-

${ }^{8}$ Michla Pomerance, "The Principle of Self Determination: Wilsonian Dilemmas and The Double Standard", di dalam John Dugard, Recognition and The United Nations, Cambridge, Grotius Publication Limited, 1987. Dikutip kembali oleh Jawahir Thontowi, "Tuntutan GAM Mengenai Self Determination Dalam Perspektif Hukum Internasional", makalah Diskusi Panel "Self Determination Dalam Perspektif Hukum Internasional, Hukum Islam dan Hukum Tata Negara", yang diselenggarakan oleh Departemen Hukum Internasional Fakultas Hukum Universitas Islam Indonesia Yogyakarta, 16 Juli 2002, HIm. 2.

${ }^{9}$ Human Right: A Compalation of International Instruments, Volume I, New York: United Nations, Centre for Human Rights Geneva, 1993, HIm. 55. Dikutip kembali oleh Jawahir Thontowi, lbid. 
Topik : Mencari Solusi Konstitusional untuk Integrasi Nasional, Ni'malul Huda

naan kekerasan yang menciptakan ketergantungan seseorang dan berakibat tertutupnya peluang bagi kemerdekaan dan penciptaan perdamaian dan upaya penyempurnaan kemerdekaan harus segera diberhentikan agar penghormatan terhadap integritas wilayah nasionalitas segera direalisasikan.

5. Tindakan segera akan diambil terhadap negara-negara yang berada dalam status perwalian dan wilayah pemerintahan yang belum memiliki pemerintahan sendiri untuk memudahkan terbentuknya kekuasaan penduduk asli tanpa ada suatu persyaratan atau penundaan.

6. Usaha apapun yang bertujuan untuk mengganggu kesatuan integritas wilayah tetapi menimbulkan gangguan adalah bertentangan dengan dan prinsip-prinsip Piagam PBB.

7. Seluruh negara wajib mematuhi secara tegas ketentuan deklarasi terbaru atas dasar prinsip kesetaraan dan tidak ada intervensi terhadap warga asing suatu negara dan wajib menghormati hak-hak kedaulatan dari seluruh orang dan integritas wilayahnya.

Disintegrasi bangsa atau separatisme (secession) merupakan salah satu bentuk konflik internal makro selain perang (eksternal) dan konflik ideologi (internal). Pada abad ke-20 terdapat kasus-kasus disintegrasi antara lain Swedia - Norwegia/ 1905; Inggris - Irlandia/1922; Otoman Turki/1923; Denmark - Eslandia/1944; Korea Utara - Selatan/1948; Jerman Barat Timur/1949; Mali - Sinegal/1960; Malaysia - Singapura/1965; Pakistan - Banglades/1971; Uni Soviet/1990; Yugoslavia/ 1991; Ethiopia - Eritria/1993; dan

\section{Cekoslovakia/1993.10}

Data tahun 1945-1995 menunjukkan terjadi 38 perang; 64 kasus separatisme dan 62 konflik ideologi/taksional. Sementara itu dari 27 kasus separatis (1944-1994) yang telah selesai diketahui bahwa 10 dimenangkan oleh Pemerintah Pusat dengan tindakan militer; dua oleh pemberontak, dan delapan daerah memperoleh otonomi (Naga/India); Basque/Spanyol; Tripura/India; Palestina/Israel; Moro/ Filipina; Chittagong Hill/Banglades; Miskito/Nikaragua; Abkhazian/Georgia). Konflik ini menghasilkan tiga negara baru (Ukraina/1991; Lithuania/1991, dan Eritria/ 1993). Selebihnya menghasilkan "de facto partion" (Kurdi, Armenia, Somali) dan "nominal power sharing" (Lebanoñ). "

Data separatisme menunjukkan beberapa hal menarik. Pertama, faktor "sejarah integrasi" apakah integrasi karena "djpaksa," "terpaksa" atau "sukarela" cukup berperan. Kedua, faktor "bentuk negara sebelumnya" apakah terdiri dari satu atau lebih cukup berperan. Ketiga, penerapan sistem Negara Federal tidak dapat berfungsi sebagai integrator jika integrasi dilakukan secara "paksa" atau karena "terpaksa" atau karena perbedaan etrik dan ekonomi. Keempat, faktor kekuatan eksternal dapat mendorong disintegrasi dan mencegah disintegrasi negara. Kelima, disintegrasi negara dapat berbentuk "total" (yang lepas lebih dari satu) maupun "partial". Keenam, perbedaan agama, etnik dan sosio-ekonomi membantu mendorong disintegrasi. Ketujuh, semakin sedikitnya

10 Iwan Gardono Sujatmiko, "Integrasi dan Disintegrasi Nasional", Kompas, 20 Desember 1999.

17 TR Gurr dalam ME Brown, 1997, dikutip kembali oleh Iwan Gardono Sujatmiko, Ibid. 
Topik : Mencari Solusi Konstitusional untuk Integrasi Nasional, Ni'matul Huda

generasi pertama integrasi yang penuh dengan emosi nasionalisme dapat mempengaruhi integrasi.

Dari peristiwa di atas sedikit banyak dapat dijelaskan melalui pengalaman berbagai negara yang pernah mengalami suatu masa seperti apa yang sekarang sedang dihadapi oleh bangsa Indonesia.

\section{Pengaturan dalam Ketatanegaraan Indonesia}

Masalah self determination sampai hari ini belum ada pengaturannya di dalam sistem hukum ketatanegaraan Indonesia. Apabila kita simak Pembukaan UUD 1945, di sana tertuang pernyataan: "Bahwa sesungguhnya Kemerdekaan itu ialah hak segala bangsa dan oleh sebab itu, maka penjajahan di atas dunia harus dihapuskan, karena tidak sesuai dengan perikemanusiaan dan peri kehidupan." Pernyataan ini sering disalahartikan bahwa Pemerintah Indonesia tidak bisa mengelak apabila ada daerah yang ingin melepaskan diri dari Negara Kesatuan Rl, karena hal itu adalah hak dari daerah. Seharusnya pernyataan itu harus dipahami sebagai pernyataan kehendak rakyat Indonesia yang ingin memerdekakan bangsanya dari segala macam penjajahan atas dirinya.

Pengalaman pahit pernah mewarnai sejarah perjalanan bangsa Indonesia, ketika Belanda memaksakan diri untuk menunjukkan kepada dunia bahwa republik yang diproklamirkan pada 17 Agustus 1945 itu sudah runtuh dan sudah tidak lagi memiliki kedaulatan. Belanda tidak hentihentinya mengusahakan segala jalan merongrong Republik Indonesia. Belanda secara terus menerus membuat "negara" di wilayah Republik Indonesia yang telah diakui de facto dalam persetujuan
Linggarjati.

Dengan disetujuinya hasil-hasi] Konferensi Meja Bundar (KMB) pada tanggal 2 November 1949 di Den Haag, maka pada tanggal 27 Desember 1949 dilakukan penandatanganan naskah "penyerahan" kedaulatan dari pemerintah Belanda. ${ }^{12}$ Negara Republik Indonesia Serikat (RIS) terdiri dari 16 negara bagian dengan masing-masing mempunyai luas daerah dan jumlah penduduk yang berbeda, yaitu tujuh negara bagian (Negara Republik Indonesia) dengan wilayah menurut status quo yang tercantum dalam persetujuan Renville tanggal 17 Januari 1948, Indonesia Timur, Pasundan, Jawa Timur, Madura, Sumatera Timur dan Sumatera Selatan dan sembilan satuan kenegaraan yang berdiri sendiri, yaitu Jawa Tengah, Bangka, Belitung, Riau, Kalimantan Barat, Dayak Besar, Daerah Banjar, Kalimantan Tenggara dan Kalimantan Timur. Diantara negara-negara bagian yang terpenting. selain Republik Indonesia yang mem-

${ }^{12}$ Tentang istilah penyerahan kedaulatan, pihak Belanda mengatakannya "penyerahan" kedaulatan kepada Indonesia, tetapi kita bangsa Indonesia menamakannya "pengembalian" atau "pemulihan" kedaulatan, sebab kitalah bangsa Indonesia yang memiliki kedaulatan atas Indonesia, yang kemudian diambil dan dirampas oleh Belanda. Kita menerima istilah penyerahan/pemulihan hanya agar Belanda lepas sama sekali dari Indonesia. Sebagai suatu taktik. Kita tolak istilah penyerahan, karena seolah-olah itu merupakan hadiah dari Belanda. Sedang pemulihan, adalah pengembalian hak kita sendiri kepada kita.Lihat dalam Tolchah Mansoer, Pembahasan Beberapa Aspek tentang Kekuasaankekuasaan Eksekutif dan Legislatif Negara indonesia, Pradnya Paramita, Jakarta, 1977, hal. 43. 
punyai daerah terluas dan penduduk terbanyak ialah Negara Sumatera Timur, Negara Sumatera Selatan, Negara Pasundan dan Negara Indonesia Timur. Republik Indonesia (Yogyakarta) merasa kedudukannya merosot dari ibukota negara Proklamasi menjadi ibukota Negara Bagian RI yang merupakan salah satu dari enam belas negara bagian RIS.

Penerimaan hasil-hasil KMB dianggap sebagai tangga untuk meningkat kepada pembulatan cita-cita rakyat, yaitu kemerdekaan yang bulat yang tak ada ikatan dengan apapun. Menjadi tuan yang sesungguhnya atas nasib sendiri. Program Negara Bagian Rl untuk mengubah Negara RIS menjadi Negara Kesatuan RI berhasil setelah Negara Bagian Sumatera Timur dan Negara Bagian Indonesia Timur setuju bergabung dengan RIS. Dengan demikian tinggallah satu Negara Bagian Rl, maka RIS mengadakan persetujuan dengan Negara Bagian Rl untuk mewujudkan Negara Kesatuan dengan mengubah Konstitusi RIS menjadi Undang-Undang Dasar Sementara (UUDS), kemudian disusul dengan proklamasi pembentukan Negara Kesatuan RI oleh Presiden Soekarno di hadapan sidang Senat dan DPRS di Jakarta pada tanggal 15 Agustus 1950. ${ }^{13}$

Pembubaran RIS dan bergabung dengan $\mathrm{RI}$ memang dimungkinkan berdasarkan Pasal 43 Konstitusi RIS, "Dalam penyelesaian susunan federasi RIS maka berlakulah asas pedoman, bahwa kehendak Rakyatlah di daerah-daerah bersangkutan yang dinyatakan dengan mer-

13 Ide Anak Agung Gde Agung, Dari Negara Indonesia Timur ke Republik Indonesia Serikat, Gadjah Mada University Press, Yogyakarta, 1985, hal. 771. deka menurut jalan demokrasi, memutuskan status yang kesudahannya akan diduduki oleh daerah-daerah tersebut dalam federasi." Keadaan ini menandakan bahwa proyek pemerintah Belanda untuk menciptakan negara federal di Republik Indonesia telah gagal total, dan rakyat Indonesia kembali ke bentuk negara kesatuan.

Munculnya berbágai tuntutan dari beberapa daerah untuk memisahkan diri dari Negara Kesatuan Rl atau merubah bangunan negara dari negara kesatuan menjadi negara serikat akhir-akhir ini, menurut Harun Alrasid, ${ }^{14}$ harus dengan syarat bahwa proses pembangunan bangsa (nation-building) dianggap sudah selesai. Setiap usaha atau gerakan yang bertujuan memecah kesatuan dan persatuan bangsa harus ditumpas. Faktor integrasi bangsa harus terus dibina dan dikembangkan. Lebih lanjut Harun mengatakan, pada waktu negara serikat diubah menjadi negara kesatuan (17 Agustus 1950), Soepomo mengatakan: "perubahan struktur negara dari bentuk federal menjadi bentuk kesatuan itu tidak melanggar konstitusi, bahkan adalah suatu kejadian konstitusional". Jadi, sebaliknya kalau terjadi perubahan dari bentuk kesatuan menjadi bentuk serikat, hal itu juga merupakan peristiwa konstitusional, dan yang terus dipertahankan sebagai wadah negara nasional adalah tetap "Republik Indonesia".

Menurut Syamsumar Dam, ${ }_{1}^{15}$ bagi negara-negara kesatuan yang pernah

${ }^{14}$ Adnan buyung Nasution, Harun Alrasid, Ichlasul Amal, dkk., Federalisme..., op.cit., hal. 8-9.

is Syamsumar Dam, "Pengalaman Negara-negara ASEAN Dalam Federalisme", dalam Adnan Buyung Nasution dkk., Ibjd., HIm. 81-82. 
Topik : Mencari Solusi Konstitusional untuk Integrasi Nasional, Ni'matul Huda

menghadapi gerakan-gerakan separatis, seperti indonesia, peralihan ke sistem federal akan cenderung mempercepat pecahnya negara-negara itu menjadi negara-negara yang merdeka. Bagi Indonesia peluang federalisme itu amat kecil, karena masalah pokok yang dihadapi bangsa Indonesia adalah mengatasi krisis kepemimpinan nasional yang mampu mengatasi krisis politik dan ekonomi yang kini dihadapi bangsa. Oleh karena itu persatuan dan kesatuan yang diikuti oleh proses demokratisasi akan lebih memberi peluang yang lebih besar daripada federalisme. Distribusi elite politik dan ekonomi yang merata ke seluruh daerah akan ikut mempengaruhi proses perkembangan gagasan federalisme itu sendiri.

Untuk merespon tuntutan beberapa daerah di atas, Pemerintah harus bertindak secara arif dan bijaksana. Dari catatan rapat Perumusan Panitia Ad Hoc I tanggal 5 April 2002 usulan di atas diakomodir kemungkinan penempatannya yang akan dibicarakan kembali dengan menyatakan sebagai berikut: "Pemisahan wilayah dari Negara Kesatuan RI hanya dimungkinkan melalui referendum nasional". Agar wilayah Negara Kesatuan RI tidak terpecah-belah, maka referendum nasional dapat dijadikan opsi bagi daerah yang ingin memisahkan diri. Akan tetapi, sebelum melangkah ke opsi tersebut Pemerintah harus mengupayakan secara sungguh-sungguh pelaksanaan otonomi yang luas bagi daerah.

Apakah otonomi daerah mampu meredam gejolak daerah untuk memisahkan diri dari Negara Kesatuan Rl dan mampu memelihara integrasi nasional? Reinhard Bendix menyatakan bahwa integrasi nasional merupakan sebuah proses perubahan loyalitas dari loyalitas yang bersifat sempit, yang bersumber dari nilai- nilai yang askriptif atau melekat dalam kelompok masyarakat, ke dalam sebuah loyalitas yang luas yang bernama "negarabangsa". Proses tersebut bermula dari pemberian atau pengakuan hak kewarganegaraan atau hak-hak politik kepada warga masyarakat yang semula tidak memilikinya. ${ }^{16}$

Untuk indonesia, proses integrasi nasional bukanlah hal yang mudah karena latar belakang sosial dan politik yang membentuk Indonesia sangat berbeda. Persoalan yang paling rumit dengan proses integrasi nasional Indonesia adalah bagaimana mengubah loyalitas yang sempit kepada loyalitas terhadap negara bangsa.

Di antara kalangan para pembentuk negara tidak banyak yang menaruh perhatian terhadap usaha pemeliharaan negara-bangsa. Salah satu tokoh yang menaruh perhatian terhadap masalah ini adalah Ir. Soekarno. Berulangkali di berbagai kesempatan, Soekarno mengingatkan warga negaranya untuk terlibat dalam proses apa yang disebutnya Nation and Character Building. Rasa cinta dan kebanggaan kepada Indonesia sebagai sebuah negara dikembangkan oleh Soekarno dan para pemimpin bangsa pada masa itu.

Namun, hal itu tidak dengan sepenuhnya berhasil. Proses integrasi nasional mengalami batu ujian yang sangat berat pada era pertengahan dan akhir tahun 1950-an. Konflik yang melibatkan kepentingan militer kemudian berhimpitan pula dengan kepentingan Pemerintah Nasional

${ }^{16}$ Syaukani, Afan Gaffar, Ryaas Rasyid, Otonomi Daerah Dalam Negara Kesatuan, Pustaka Pelajar kerjasama dengan Pusat Pengkajian Etika Politik dan Pembangunan, Yogyakarta, 2002, HIm. 264. 
dengan pemerintah daerah. Selanjutnya menjadi bertambah kompleks dengan munculnya dimensi etnisitas, wilayah, dan agama dalam konflik di Indonesia.

Sampaí berakhirnya kekuasaan Soeharto pun, ancaman terhadap integrasi nasional masih selalu membayangi. Disadari atau tidak, dan diakui atau tidak, pada masa Orde Baru itulah sebenarnya terjadi proses "Jawanisasi" yang dilakukan oleh Jakarta ataupun orang-orang di Daerah. Segala bentuk kebijaksanaan dari pemerintah daerah harus mendapat pengesahan dan pengakuan dari Jakarta, kalau tidak, tidak ada artinya sama sekali.

Di sinilah sebenarnya bibit-bibit ancaman terhadap integrasi nasional mulai dikembangkan. Rasa ketidakpuasan terhadap Jakarta dimunculkan secara diam-diam dan terbuka. Ketimpangan dalam distribusi pendapatan nasional berakumulasi pula dengan munculnya semangat "micronationalism", maka persoalan pemeliharaan sebuah "nation state" merupakan tantangan yang sangat luar biasa yang dihadapi oleh pemerintah dan bangsa Indonesia sekarang ini. Ancaman kemungkinan terjadinya disintegrasi bangsa merupakan sesuatu yang nyata, apalagi pada saat sekarang ini Pemerintah mengalami kesulitan untuk menemukan modus operandi yang tepat menghadapi gerakan bersenjata seperti di Aceh. ${ }^{17}$

Alexis de Tocqeville seperti dikutip oleh Rienow mengatakan, bahwa pemerintahan merdeka tanpa semangat membangun institusi pemerintahan tingkat daerah sama artinya dengan tidak mempunyai semangat kedaulatan rakyat karena

17 Ibid, hal. 273. disana tidak ada semangat kebebasan. ${ }^{18}$ Administrasi pemerintahan yang terlalu bersifat sentralistis terbukti kurang efektif melayani kepentingan-kepentingan daerah, untuk itu harus diimbangi dengan sistem yang lebih desentralistis, dengan memperluas wewenang atau otonomi pemerintahan daerah.

Dengan otonomi maka akan tercipta mekanisme, dimana daerah dapat mewujudkan sejumlah fungsi politik terhadap pemerintahan nasional, hubungan kekuasaan menjadi lebih adil sehingga dengan demikian daerah akan memiliki kepercayaan dan akhirnya akan terintegrasi ke dalam pemerintahan nasional. Dengan otonomi, maka proses demokrasi dapat dijalankan yang juga akan menopang terwujudnya demokrasi dalam pemerintahan, dan pada akhirnya pembangunan daerah akan dipercepat.

\section{Solusi Konstitusional Bagi Aceh dan Irian Jaya}

Momentum reformasi di Indonesia memberi peluang bagi timbulnya pemikiran dan kesadaran baru untuk menyelesaikan berbagai permasalahan besar bangsa Indonesia dalam menata kehidupan berbangsa dan bernegara yang lebih baik. Sehubungan dengan itu, MPR RI menetapkan perlunya pemberian status otonomi khusus kepada Propinsi Daerah Istimewa Aceh dan Propinsi trian Jaya sebagaimana diamanatkan dalam ketetapan MPR RI No. IV/MPR/ 1999. Dalam Ketetapan MPR RI No.W/ MPR/2000 tentang Rekomendasi Kebijakan Dalam Penyelenggaraan Otonomi Dae-

${ }^{18}$ Robert Rienov. 1996. Introduction to Government, Alfred A. Koof, New York, hal. 573. 
Topik : Mencari Solusi Konstitusional untuk Integrasi Nasional, Ni'matul Huda

rah, yang antara lain menekankan tentang pentingnya segera direalisasikan otonomi khusus tersebut melalui penetapan suatu undang-undang otonomi khusus bagi Propinsi Daerah Istimewa Aceh dan Propinsi Irian Jaya dengan memperhatikan aspirasi masyarakat. Hal ini merupakan suatu langkah awal yang positif dalam rangka membangun kepercayaan rakyat kepada Pemerintah sekaligus merupakan langkah strategis untuk meletakkan kerangka dasar yang kukuh bagi berbagai upaya yang perlu dilakukan demi tuntasnya penyelesaian masalah-masalah di Propinsi Daerah Istimewa Aceh dan Propinsi Irian Jaya.

Pemberian otonomi khusus bagi Propinsi Daerah Istimewa Aceh antara lain didasarkan pada kondisi riil masyarakat Aceh yang belakangan ini memunculkan pergolakan dalam berbagai bentuk reaksi, akibat kebijakan dalam penyelenggaraan pemerintahan pada masa lalu yang menitikberatkan pada sistem yang terpusat dipandang sebagai sumber bagi munculnya ketidakadilan dalam kehidupan berbangsa dan bernegara. Dan apabila hal tersebut tidak segera direspons dengan aktif dan bijaksana maka akan dapat mengancam keutuhan Negara Kesatuan RI.

Berdasarkan kondisi tersebut di atas MPR pada Sidang Umum 1999 merumuskan dalam Garis-garis Besar Haluan Negara 1999 kebijakan yang menyangkut dengan Pembangunan Daerah menetapkan Ketentuan Khusus untuk tiga propinsi, yaitu: 1) Daerah Istimewa Aceh, 2) Irian Jaya dan 3) Maluku. Di dalam keterangan pemberian status khusus itu disebutkan:

"Dalam rangka pengembangan otonomi daerah di dalam wadah Negara Kesatuan Republik Indonesia, serta untuk menyelesaikan secara adil dan menyeluruh permasalahan di daerah yang memerlukan penanganan segera dan bersungguhsungguh...".

Untuk Daerah Istimewa Aceh, ditetapkan bahwa:

(a) Mempertahankan integrasi bangsa dalam wadah Negara Kesatuan Republik Indonesia dengan menghargai kesetaraan dan keragaman kehidupan sosial budaya masyarakat Aceh, melalui penetapan Daerah Istimewa Aceh sebagai daerah otonomi khusus "yang diatur dengan undang-undang".

(b) Menyelesaikan kasus Aceh secara berkeadilan dan bermartabat dengan melakukan pengusutan dan pengadilan yang jujur bagi pelanggar hak asasi manusia, baik selama pemberlakuan Daerah Operasi militer maupun pasca pemberlakuan daerah Operasi Militer.

Kalau diktum yang ditetapkan untuk menentukan Aceh sebagaj Daerah Otonomi Khusus diperhatikan, maka ada beberapa kata kunci yang harus diperhatikan. Pertama, mempertahankan integrasi bangsa dalam wadah Negara Kesatuan Rl. Kedua, menghargai kesetaraan dan keragaman kehidupan masyarakat Aceh. Ketiga, penyelesaian kasus-kasus di Aceh secara berkeadilan dan bermartabat. Keempat, melakukan pengusutan pengadilan terhadap pelanggar HAM di Aceh, dan kelima, pemberlakuan daerah otonomi khusus itu diatur dengan undang-undang. Kelima kata kunci tersebut tentu saja harus menjadi perhatian dan pegangan pemerintah di dalam berusaha menyelesaikan masalah Aceh."

19 Anhar Gonggong, Amandemen..., Op.Cit., hal. 92. 
Pada Sidang Tahunan MPR 2000 telah dikeluarkan Ketetapan MPR No. IV/ MPR/2000 yang merekomendasikan agar undang-undang otonomi khusus bagi Daerah Istimewa Aceh dapat dikeluarkan selambat-lambatnya bulan Mei 2001. Sebagai tindak lanjut dari rekomendasi tersebut, dikeluarkanlah UU No. 18 Tahun 2001 tentang Otonomi Khusus Bagi Propinsi Daerah Istimewa Aceh Sebagai Propinsi Nanggroe Aceh Darussalam.

Undang-undang ini pada prinsipnya mengatur kewenangan pemerintahan di propinsi Daerah Istimewa Aceh yang merupakan kekhususan dari kewenangan pemerintahan daerah, selain sebagaimana yang diatur dalam UU No. 22 Tahun 1999 tentang Pemerintahan Daerah dan UU No. 25 Tahun 1999 tentang Perimbangan Keuangan antara Pusat dan Daerah.

$\mathrm{Hal}$ mendasar dari undang-undang ini adalah pemberian kesempatan yang lebih luas untuk mengatur dan mengurus rumah tangga sendiri termasuk sumbersumber ekonomi, menggali dan memberdayakan sumber daya alam dan sumber daya manusia, menumbuhkembangkan prakarsa, kreativitas dan demokrasi, meningkatkan peran seíta masyarakat, menggali dan mengimplementasikan tata bermasyarakat sesuai dengan nilai luhur kehidupan masyarakat Aceh, mengfungsikan secara optimal DPRD Propinsi Nanggroe Aceh Darussalam dalam memajukan penyelenggaraan pemerintahan di Propinsi Nanggroe Aceh Darussalam dan mengaplikasikan syariat Islam dalam kehidupan bermasyarakat.

Undang-undang ini menempatkan titik berat otonomi khusus pada Propinsi Nanggroe Aceh Darussalam yang pelaksanaannya diletakkan pada daerah Kabupaten dan Kota atau nama lain secara proporsional. Kekhususan ini merupakan peluang yang berharga untuk melakukan penyesuaian struktur, susunan, pembentukan dan penamaan pemerintahan di tingkat lebih bawah yang sesuai dengan jiwa dan semangat berbangsa dan bernegara yang hidup dalam nilai-nilai luhur masyarakat Aceh.

Sedangkan untuk Propinsi Irian Jaya pemerintah mengeluarkan UU No. 21 Tahun 2001 tentang Otonomi Khusus Bagi Propinsi Papua. Otonomi khusus bagi Propinsi Papua pada dasarnya adalah. pemberian kewenangan yang lebih luas bagi Propinsi dan rakyat Papua untuk mengatur dan mengurus diri sendiri di dalam kerangka Negara Kesatuan RI. Kewenangan yang lebih luas berarti pula tanggung jawab yang lebih besar bagi Propinsi dan rakyat Papua untuk menyelenggarakan pemerintahan dan mengatur pemanfaatan kekayaan alam di Propinsi Papua untuk sebesar-besarnya bagi kemakmuran rakyat Papua sebagai bagian dari rakyat Indonesia sesuai dengan peraturan perundang-undangan. Kewenangan ini berarti pula kewenangan untuk memberdayakan potensi sosial budaya dan perekonomian masyarakat Papua, termasuk memberikan peran yang memadai bagi orang-orang asli Papua melalui para wakil adat, agama, dan kaum perempuan. Peran yang dilakukan adalah ikut serta merumuskan kebijakan daerah, menentukan strategi pembangunan dengan tetap menghargai kesertaan dan keragaman kehidupan masyarakat Papua, melestarian budaya serta lingkungan alam Papua, yang tercermin melalui perubahan nama !rian Jaya menjadi Papua, lambang daerah dalam bentuk bendera dan lagu daerah sebagaj bentuk aktualisasi jatj dirj rakyat Papua dan pengakuan terhadap eksistensi 
Topik : Mencari Solusi Konstitusional untuk Integrasi Nasional, Ni'matul Huda

hak ulayat, adat masyarakat adat dan hukum adat.

Undang-undang ini mengandung semangat penyelesaian masalah dan rekonsiliasi, antara lain dengan pembentukan Komisi Kebenaran dan Rekonsiliasi. Pembentukan Komisi ini dimaksudkan untuk menyelesaikan berbagai permasalahan yang terjadi di masa lalu dengan tujuan memantapkan persatuan dan kesatuan nasional Indonesia di Propinsi Papua.

\section{Penutup}

Rasanya terlalu dini kalau memberikan penilaian atau bahkan merevisj kebijakan dalam bidang otonomi daerah seperti yang ramai dibicarakan masyarakat, tetapi kita terus berharap otonomi daerah dapat menjadi solusi alternatif bagi bersoalan integrasi nasional. Untuk itu, secara bersama-sama pemerintah dan masyarakat harus terus mengupayakan supaya otonomi daerah dapat berjalan seperti yang diharapkan, dan melakukan kajian serta evaluasi terus menerus agar dapat diantisipasi sedini mungkin kemungkinan adanya penyelewengan dalam implementasinya, seperti yang sering dikeluhkan akhir-akhir ini.e

\section{Daftar Pustaka}

Nasution, Adnan Buyung, dkk.,1999. Federalisme Untuk Indonesia, Penerbit Kompas Media Nusantara, Jakarta.
Gonggong, Anhar. 2001. Amandemen Konstitusi, Otonomi Daerah dan Federalisme, Solusi Untuk Masa Depan, Media Pressindo, Yogyakarta.

Ide Anak Agung Gde Agung, 1985. Dari Negara Indonesia Timur ke Republik Indonesia Serikat, Gadjah Mada University Press, Yogyakarta.

Thantowi, Jawahir, "Self Determination Dalam Perspektif Hukum Internasional", makalah diskusi panel "Self Determination Dalam Perspektif Hukum Internasional, Hukum Islam dan Hukum Tata Negara", yang diselenggarakan Departemen Hukum Internasional FH UII, 16 Juli 2002.

Ohmae, Kenichi. 2002. Hancurnya NegaraBangsa, Penerbit Qalam, Yogyakarta.

Jardine, Matthew. 1995. East Timor: Genocide in Paradise, Odonian Press, Tucson, Arizona.

Rienov, Robert. 1996. Introduction to Government, Alfred A. Koof, New York. .

Syaukani, Gaffar Afan, Ryaas Rasyid. 2002. Otonomi Daerah Dalam Negara Kesatuan, Pustaka Pelajar kerjasama dengan Pusat Pengkajian Etika Politik dan Pemerintahan, Yogyakarta.

Mansoer, Tolchah. 1977. Pembahasan Beberapa Aspek tentang Kekuasaan-kekuasaan Eksekutif dan Legislatif Negara Indonesia, Pradnya Paramita, Jakarta,

Kompas, 20 Desember 1999.

Kompas, Minggu, 19 Mei 2002.

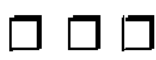

